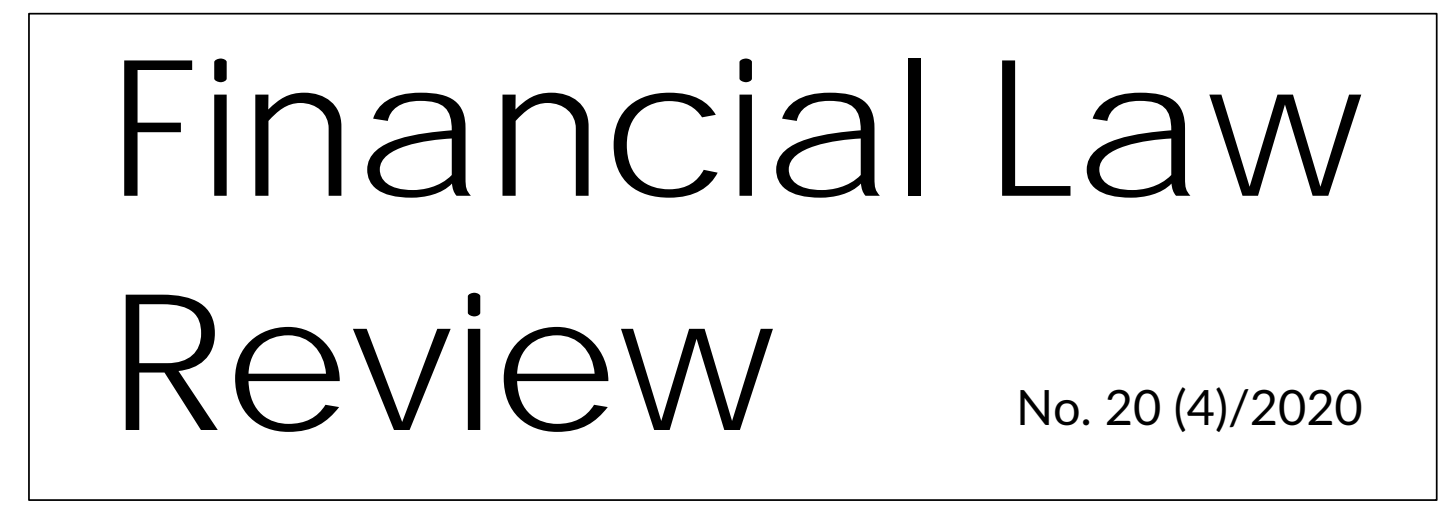

UNIVERSITY OF GDAŃSK • MASARYK UNIVERSITY • PAVEL JOZEF ŠAFÁRIK UNIVERSITY • UNIVERSITY OF VORONEZH http://www.ejoumals.eu/FLR

\title{
TAXATION OF DIGITAL SERVIECES FROM INTERNATIONAL TAX LAW PERSPECTIVE ${ }^{1}$
}

\begin{abstract}
The article analyses taxes on digital services adopted in the United Kingdom, France, Austria, and Italy. The article tries to identify the architectural features of these taxes that could conflict with obligations according to international tax treaties and EU laws. The article also presents OECD "Unified Approach" which is based on multilateral agreement. The main hypothesis of the article is that this approach represents a better solution for the taxation of digital services than unilateral national taxation of digital services. In the presented analyses, mainly horizontal comparative method, method of logical analysis and synthesis are employed.
\end{abstract}

Key words: tax law, tax on digital services, OECD, international tax law, EU law.

JEL Classification: K34

\footnotetext{
* The author is researcher at the Department of Financial Law, Tax Law and Economy, Faculty of Law, Pavol Jozef Šafárik University in Košice, Slovak Republic. The author specializes mainly in the area of procedural tax law, international taxation law and the law of European Union. He is author of 1 scientific monographs, co-author of 2 scientific monographs and author of more than 15 scientific papers.

Contact email: jozef.sabo@upjs.sk.

${ }^{1}$ This work was supported by the Slovak Research and Development Agency uder the Contract no. APVV-19-0124.
} 


\section{Introduction}

Innovations in the field of economy recently brought some significant changes by which corporations create value when doing businesses. A progress in technological development will necessarily require changes in the way of achieving income for public budgets. Currently we are witnesses of the presumptions under which: „it will be rather technology and not tax policy, which will accelerate tax regulations in many areas" [Cockfield 2002: 368]. This fact has been already recognized by The Organisation for Economic Co-operation and Development (hereinafter referred to as "OECD”) when preparing the tax base erosion and profit shifting initiative (hereinafter referred to as "BEPS"). New business models on the basis of advanced digitalization caused essential changes from the view of international taxation. The former position presented at the OECD forum that "no significant change compared to the current state of play is needed" was replaced by the acknowledgement that "rules of the source state are not sufficient enough for current models of digital economy" [Olbert, Spengel 2017: 8].

State legislators face difficult decisions in respect to the taxation of the digital economy. The most pressing issue right now is the taxation of digital services. We could distinguish two approaches toward the taxation of the digital economy:

- $\quad$ OECD proposed adoption of multilateral agreement by changing existing rules governing international taxation in respect to digital services.

- Second approach prefers the introduction of new tax measures to national legislation specifically aimed at the taxation of the digital economy. These new instruments are predominantly designed as digital service taxes (hereinafter referred to also as "DST").

This article will focus on the limitation of taxation power imposed on a national state by the existing net of international treaties especially double taxation treaties and General Agreement on trade in services (hereinafter referred to as "GATS"). In paper we will try verify, whether there exists, with relation to DST, a significant risk of conflict with international law. If the above hypothesis is confirmed, we will continue to verify the subsequent partial hypotheses:

- $\quad$ which parts of the architecture of DST greatly contribute to that risk?

- Is it feasible to adopt DST in the way that the risk of breach of international obligation by this unilateral approach is minimalized? 
The article will be divided into three parts. The first part will deal with OECD approach to the taxation of digital services. The second part will focus on the main features of the selected DSTs and their potential conflict with international law.

As for the existing literature, there are a very limited number of papers concerning specifically legal aspects of DSTs. For example Hrabčák a Popovič stressed the importance to adopted new approaches towards taxation of digital services [Hrabčák, Popovič 2019]. The main body of the works already adopted DST are mainly in the form of internet articles. On the other hand, there exist plenty of works concerning issues that directly relate to the legal status of tax legislation in international tax law [e.g. Avi-Yonah 2003] and EU law [e.g. Terra, Wattel 2004] .General issues concerning taxation were also covered by number of publications [e.g. Babčák 2020].

\section{OECD work on digital taxation}

Sufficient connection between the taxed activity/taxable person generating this income and the territory of the state is required for the tax right of the state to arise. This connection is also called "nexus" and it is a notion representing the necessary closeness for the right to tax. "Source rules are important for foreign nonresidents because they are taxed only on domestic source income. In the case of non- residents, the definition of source therefore controls taxation in the source country. Source rules might seem to be unimportant for residents, because residents of global jurisdictions are taxed on all income from whatever source derived from" [Avi-Yonah 2003: 38]. Tax residency according to Art. 4 (1) of the OECD Model Tax Convention Model Tax Convention on Income and Capital 2017 (hereinafter referred to as "OECD Model Tax Convention") covers: "any person who, under the laws of that State, is liable to tax therein by reason of his domicile, residence, place of management or any other criterion of a similar nature, and also includes that State and any political subdivision or local authority thereof as well as a recognised pension fund of that State." Secondly, a state can impose a tax on income with the source being situated in that state when the person performing activities, which gives rise to that income, has a physical presence in the territory of the state (also called "permanent establishment"'). Permanent establishment according to Art. 5 of the OECD Model Tax Convention defines as: "for the purposes of this Convention, the term "permanent establishment" means a fixed place of business through which the business of an enterprise is wholly or partly carried on" (including: a place of management; a branch; office; factory; workshop, and mine, oil or gas well, a quarry or any other place of extraction of natural resource). Providers of digital services allow their customers to access 
digital services remotely via digital e.g., via internet. Often, internet tech companies do not need to be physically present in the territory where the source of income from digital services is located. Thus, they can circumvent provisions concerning permanent establishment. "The digital economy is characterised by an unparalleled reliance on intangibles, the massive use of data (notably personal data)." [OECD 2015]. As a result, income is not taxed in the country where the value is created, instead taxation rights are granted for countries of the origin of taxpayers.

Noticing the need for a change in the current regime, OECD adopted a document by the name Action 1 Addressing the Tax Challenges of the Digital Economy. OECD divides its work on the future state of digital taxation into two pillars. Pillar One covers the development of a new nexus and new rules for the distribution of profit between states that go beyond the current arm's length principle. Moreover, Pillar One proposed the implementation of a new effective mechanism for the resolution of tax dispute. Pillar Two covers other BEPS issues, especially the risk of undertaxation of income from digital services.

At the beginning, three alternatives on the taxation of digital services were considered: the "user participation" proposal, the "marketing intangibles" proposal, and the "significant economic presence" proposal. "User participation" proposal considers as the most important criterium place, where an active and engage user base of digital services is situated. A country, in which such active user base is located, would be granted taxation rights on residual profit even without the need of physical presence/activity of a taxpayer. "The proposal would modify current profit allocation rules to require that, for certain businesses, an amount of profit be allocated to jurisdictions in which those businesses' active and participatory user bases are located, irrespective of whether those businesses have a local physical presence" [OECD 2019b: para 22]. This proposal mainly aims to tax social media platforms, search engines, and online marketplaces. Second proposal, the marketing „intangibles" proposal, would grant taxation rights to the county where marketing intangibles are sold. For example, marketing intangibles are customer lists, customer relationships, and proprietary market and customer data that is used or aids in marketing and selling goods or services to customers [OECD 2019b: para 32]. Final proposal is the "significant economic presence", the proposal, which designates significant economic presence as condition for the taxation rights to exist. Significant economic presence would be determined by several factors, for example: the existence of a user base and the associated data input; the volume of digital content derived from the jurisdiction; billing and collection in local currency or with a local form of payment; the maintenance of a website in a local language; responsibility for the final delivery of goods to customers or 
the provision by the enterprise of other support services such as after-sales service or repairs and maintenance; or sustained marketing and sales promotion activities, either online or otherwise, to attract customer "Non-resident enterprise has a significant economic presence on the basis of factors that evidence a purposeful and sustained interaction with the jurisdiction via digital technology and other automated means" [OECD 2019b: para 51]. First alternative for the implementation of one of these new nexus rules is to amend Articles 5 and 7 of the OECD Model Tax Convention to deem permanent establishment to exist in case of remote yet sustained and significant involvement of the taxpayer in the economy exists. Moreover, impacted would be Articles 10- 13, 15, 21, 22, and 24 of the OECD Model Tax Convention. Second alternative is the introduction of a new standalone provision giving the market jurisdiction a taxing right [OECD 2019c, part 2.1].

Specific model for Pillar One was presented in January 2020 under the name „Unified Approach” [OECD 2020b]. This Unified Approach proposes the adoption of a „Three Tier Mechanism." The Three Tier Mechanism distinguishes between three mechanisms for allocation of income:

- Amount $\mathrm{A}$ : introduces new tax rights to tax a portion of multinational enterprise's (hereinafter referred to as "MNE") deemed residual profit. Residual profit would be the profit that remains after allocating what would be regarded as a deemed routine profit on activities to the countries where the activities are performed.

- $\quad$ Amount B: means profit taxable under the same arm's length rules as are in force now [OECD Model Tax Convention: Art. 7].

- Amount C: proposes the creation of a new dispute resolution mechanism [OECD 2020b: para 30].

Achieving the multilateral agreement on measures on Pillar One is significant also regarding DST because several states proposed that they postpone the application/adoption of national DST only until the end of the year 2020.

Proposed changes are ambitious at least. Tax jurisdiction is a core aspect of the sovereignty of each state. Every state tries to obtain new tax sources for their public revenues. On the other, there is an effort to defend national taxpayers from extensive taxation abroad (especially from the viewpoint of US, where the majority of tech companies are located). Both are very sensitive to political issues. Therefore, it is questionable if political consensus on the Unified Approach would be reached in these volatile times. 


\section{DSTs and potential breach of international obligations}

There are several voices who stress the importance of new approach towards the taxation of digital services. "New principle should be also stabilized, namely, the principle of taxation in the place where value and profit are actually generated" [Hrabčák, Popovič 2019: 58]. Certain states have already adopted DST into their national legal system (e.g. Italy, France, Austria). Other states have laid out their plans for the introduction of DST in future (e.g., Czech Republic). Future introduction of DST is also a position of EU tax policy - Commission has introduced a proposal for harmonized DST in the document Proposal for a Council Directive on the common system of a digital services tax on revenues resulting from the provision of certain digital services \{SWD(2018) 81\} - \{SWD(2018) 82\} of 21 March 2018.

In this chapter, we will discuss four selected DSTs. Namely, we will analyse "digital service tax" adopted by the United Kingdom (hereinafter referred to as "UK: DST"), "l'imposta sui servizi digitali" implemented in Italy (hereinafter referred to as "IT: DST"). "Werbeabgabe" that was adopted by Austria (hereinafter referred to as "AU: DST") and maybe the most "famous" French: "TCA - Taxe sur certains services fournis par les grandes entreprises du secteur numérique" (hereinafter referred to as "FR:DST"). With respect to France, tax law has always a strong position in national fiscal policy. "The autonomy of the tax law and the theory of legal realism in the tax law were so important that when the theory of the autonomy was introduced." Therefore, as we show further, FR:DST covers more types of digital services than other analysed DST (except for IT:DST). Maybe it is the reason FR: DST have been already heavily criticised by US authorities. For better clarity of our analyses, we will focus our analyses into four categories: Scope, Nexus, Threshold Conditions and Tax Rates.

\subsection{Outline of selected DSTs}

The UK: DST is charged on "UK digital services revenue". UK digital services revenues are defined as revenues that come from social media services, internet search engines, and online marketplaces. [Finance Bill 2020: part 2., Art. 42(1)]. Moreover IT: DST is levied in connection with similar types of digital services, namely: (a) digital interface of advertising aimed at users of the same interface (e.g., online marketplace), (b) multilateral digital interface that allows users to be in contact and interact with each other (e.g. social media service) and (c) transmission of data collected from users and generated using a digital interface (e.g. an internet search engine) [Budget Law 2020: Art. 37]. The taxable revenues are calculated as a percentage of the MNEof 's worldwide total revenues. This percentage 
represents how many of these services are provided in Italy. For targeted advertising and online marketplaces, it is the number of advertising messages placed on a digital interface, and/or the proportion of users to whom the data was sold in Italy. For a digital interface (multilateral digital interface facilitating the sale of goods and services), this percentage is determined by the number of delivery operations of goods or services from or into the territory of the state. Similarly, the FR:DST is levied on gross revenues generated by (a) "digital interface" services and (b) "targeted advertising" services. The FR:DST determines taxable revenues as a percentage of MNEof 's total worldwide revenue in the similar way as IT: DST. For digital inference, this percentage is the number of transactions carried out during the month where the buyer or seller is in France. Percentage of targeted advertising is calculated by either the total number of advertising impressions made during the month or by the number of users whose data has been sold since the start of the year [French DST Law: Art. 299(1)].

In Austria, only online advertising services fall within the scope of AU:DST - when they are provided by online advertising companies in Austria for a fee [Digital Tax Act 2020: Art. 1(1)]. The tax debtor is the online advertising provider - the person who is entitled to a fee for the implementation of an online advertising service. Online advertising provider is a subject to taxation whereas they own the digital interface or not. "Digital Interface" means any type of software (including websites or parts thereof and mobile applications) that users can access [Digital Tax Act 2020: Art. 2(3), 4(1)]. Tax burden is imposed on the fee that the online advertising company receives from a client. This is reduced by expenses for preliminary work by other online advertising companies that are not part of his multinational group of companies [Digital Tax Act 2020: Art. 3(1)]. We believe that of all four analysed taxes, only AU:DST could only be considered as "pure" indirect tax. Although other DSTs are constructed as turnover taxes, they are more akin to direct taxes.

Two DSTs (IT: DST and FR:DST) employ (IP) address for determination, whether there was a digital service provided within their tax jurisdiction. Thus, digital services are deemed to be provided in Italy or France when performed on user's device that has matching Italian or French IP address. Furthermore, a device could be deemed to be in Italy also from other information provided by geolocation systems under the condition that they comply with rules for the protection of personal data [Budget Law 2020: para. 40, 40-bis]. For "digital interface" services to be performed in France, it is necessary that either one of the users (the seller or purchaser of goods or services via the digital interface) is located in France or that the user from France opens an account on the digital interface during the taxation period. In case of "targeted advertising" services, they are provided in France when either 
data are generated by or collected from French users or an advertisement is placed on the digital interface who visits this interface, while in France [French DST Law: Art. 299].

On the other hand, UK: DST employs a wider legal notion of "UK user." This term means any user for whom it is reasonable to assume that is normally in the United Kingdom or who is established in the United Kingdom [Finance Bill 2020: part 2., Art 43(3)]. With respect to marketplace transactions, digital services are performed in the UK when a user is a transaction's party, or transaction arise in connection with accommodation or land in the UK. For online advertising revenue, it is required that either the UK user pays for the advertisement or that the advertisement is viewed or otherwise consumed by UK users. [Finance Bill 2020: part 2., Art 40(4-8)]. The AU:DST used a mixed approach an online advertising service is deemed to have been provided domestically, if it is received on the device of a user with a domestic IP address and its content and design are (also) aimed at domestic users [Digital Tax Act part 2., 2020: Art. 1(1)].

All DSTs prescribe threshold conditions for a person to be covered under taxation. The taxpayers of DSTs are only these companies who belong to the group that meet these threshold conditions. In the UK:DST taxpayer is subjected to tax if: (a) total amount of digital services revenue arising to all members of his group exceeds $£ 500$ million, and (b) the total amount of UK digital services revenue arising in that period to all members of the group exceeds $£ 25$ million. Taxable is only the part of UK digital services' revenue that exceed $£ 25$ million [Finance Bill 2020: part. 2, Art 40(4-8)]. In other analysed DSTs, the numbers of threshold conditions are quite similar. IT: DST requires that (a) total amount of digital services earned by all members of the group exceeds $€ 750$ million, and (b) the total amount of revenues derived from taxable digital services performed in Italy exceeds $€$ 5,5 million [Budget Law 2020: Art. 36, 41]. The AU: DST's threshold conditions require (a) worldwide turnover for digital services to reach at least $€ 750$ million and (b) domestic sales of digital advertising reach at least 25 million euros [Digital Tax Act 2020: Art. 2(2)]. FR:DST prescribes threshold conditions for (a) the total amount of revenue from digital services for all members of the group exceeds $€ 750$ million, and (b) revenue from taxable digital services performed in France exceeds $€ 25$ million during the previous calendar year [French DST Law: Art. 299(3)]. We can observe that in all cases states employ very similar threshold conditions to build on two-tier mechanism - separate threshold is set for worldwide gross revenue and separate for domestic turnover.

The individual states follow very similar DST' tax rates between the range from 2 to 5 percent. The UK: DST employs $2 \%$ tax rate [Finance Bill 2020: part. 2, Art. 46]. In Italy, the tax rate of IT: DST is 3 \% [Budget Law 2020: Art. 41]. The FR: DST has a tax rate at $3 \%$ 
[French DST Law: Art. 299(4)]. Austria adopted the highest tax rate at 5\% [Digital Tax Act 2020: para. 3]. On the other hand, the AU:DST has the narrowest scope (tax covers only digital advertisements).

In the United Kingdom and in Italy, DSTs are payable annually. UK: DST is payable on the day following the end of 9 months from the end of the accounting period [Finance Bill 2020: part. 2, Art. 50]. IT:DST, the tax is payable on February 16 of the following calendar year. FR: DST is paid by two instalments in that same year. In the AU:DST is tax payable by the 15th of the second following month after the tax claim arises.

\subsection{Analysis of selected DSTs}

Threshold conditions are the main architectural part of DST that could be discriminatory to foreign taxpayers. The first tier threshold conditions for - the worldwide required turnover selects primarily big tech companies that conduct business across the globe. According to the findings of the Report on France's Digital Services Tax that was published by Office of the United States Trade Representative (hereinafter referred to as "Report") from twentyseven companies that would be covered under FR:DST approximately seventeen are companies located in the US. Two-thirds of all covered companies would be US tech companies, which is, in our opinion, a staggering number. In that respect to the similar worldwide threshold adopted by other tax jurisdictions, we can conclude that these findings apply to all analysed DSTs. With that respect analysed DSTs may conflict with tax treaties and EU laws due to:

- $\quad$ their discriminatory nature;

- $\quad$ a conflict with international tax principles for taxation of income;

- a conflict with international tax principles concerning territorial taxation;

- a conflict with EU state aid rules;

- $\quad$ a conflict with EU laws.

\section{GATS}

GATS covers all measures by members affecting trade in services (GATS: Art. I). The term "service" includes any service in any sector except services supplied in the exercise of governmental authority. Therefore, digital services fall inside the scope of GATS. In that respect, GATS prescribes two main requirements for the treatment of internationally 
provided digital services namely "Most-Favoured-Nation Treatment" and "National Treatment". Most-Favoured-Nation Treatment means that with respect to any measure covered by this Agreement, each Member shall accord immediately and unconditionally to services and service suppliers of any other Member treatment no less favourable than that it accords to like services and service suppliers of any other country (GATS: Art. II). Thus, under "Most-Favoured-Nation Treatment" a state is obliged to treat all services provided by entities located in all other GATS member states equally. Therefore, the discriminatory treatment towards any of the other member states is prohibited. With that in mind, DSTs are problematic in two aspects. Firstly, policy goals that lead to the adoption of DSTs could be viewed as questionable at least. Several political statements explicitly or implicitly connected the introduction of DSTs to the taxation of US tech companies. FR: DST, for example, is widely known under the nickname "GAFA" (which is an abbreviation of the names of four big tech companies, Google, Amazon, Facebook, Apple - all situated in US). Secondly, as was demonstrated above, worldwide threshold conditions pinpoint predominantly US tech companies as taxpayers of DST.

The adoption of turnover DSTs means that the tax burden that would be nominally imposed on taxpayer would be subsequently shift on customers of digital services. As a result, US tech companies, which would be affected by DST, would provide their services at higher costs and with higher administrative burden. On the other hand, companies that do not meet this worldwide threshold condition (which are companies mostly from other countries than US) would operate and provide their digital services free of digital tax. In that respect, DST could have a direct discriminatory effect towards US tech companies. Furthermore, the exception for Most-Favoured-Nation Treatment granted under Art. $\mathrm{XIV}(\mathrm{e})$ of $\mathrm{GATS}^{2}$ would not cover the kind of DSTs which would constitute a means of arbitrary or unjustifiable discrimination between countries (Art IX of GATS).

Moreover, there exists a risk that DSTs would discriminate between domestic and foreign digital services. This kind of discrimination that is prohibited under GATS National Treatment. According to Art. XVII of GATS: "In the sectors inscribed in its Schedule, and subject to any conditions and qualifications set out therein, each Member shall accord to services and service suppliers of any other Member, in respect of all measures affecting the supply of services, treatment no less favourable than that it accords to its own like services and service suppliers." It means that member states should treat services provided

\footnotetext{
${ }^{2}$ Exception under Art. XIV(e) of GATS covers measures inconsistent with Article XVII, provided that the difference in treatment is aimed at ensuring the equitable or effective 6 imposition or collection of direct taxes in respect of services or service suppliers of other Members.
} 
from abroad equally with services provided domestically. On the other hand, there is a general exemption from this obligation that is expressed in Art. XIV(d) of GATS nothing in this Agreement shall be construed to prevent the adoption or enforcement by any Member of measure inconsistent with Article XVII, provided that the difference in treatment is aimed at ensuring the equitable or effectiveb imposition or collection of direct taxes in respect of services or service suppliers of other Members. This general exemption leads certain authors to the conclusion that DST are not covered under "National Treatment" provision of GATS [Shiers, Stoels 2019]. Therefore, the states' obligation under Nation Treatment may not be infringed by imposing DSTs specifically designed on two-tier threshold conditions.

\section{EU Law}

Although the legal framework of GATS offers an exemption for, inter alia, domestic discriminatory treatment of digital services, it is not the case in EU law. For example, if too high national revenue thresholds for DSTs are set, this could lead to a similar situation as with high worldwide thresholds. The higher the national revenue threshold is to be set, the more domestic companies providing digital services would be exempt from taxation. Subsequently, this would lead to the indirect discrimination of big foreign companies with big market share - who, as we know, are usually US. Similarly, when DSTs are adopted with too narrow scope in mind services, which are alike to digital services, are not covered by taxation. In this situation, discrimination against foreign services in favour of similar domestic services could happen. As an example, we can mention digital advertising and advertising in print.

The meeting of the threshold conditions triggers tax liability for all members of the group. Therefore, if that MNE establishes its subsidiarity in any of the EU member states, that subsidiary would be covered under the same DST's regime as all members of the group. However, there is one important difference. The subsidiary established in any member state can really on the protection provided by EU law. Digital services fall within the scope of services covered by the freedom to provide services according to the Art. 56 of Consolidated versions of the Treaty on European Union [OJ C 202, 7.6.2016, p. 1-388 (hereinafter referred to as "TFEU")] ]. "The freedom to provide services encompasses a right for the service provider to enter and to sojourn (market access) and a right to be treated in the same

\footnotetext{
${ }^{3}$ Art. 56 of TFEU states that within the framework of the provisions set out below, restrictions on freedom to provide services within the Union shall be prohibited in respect of nationals of Member States who are established in a Member State other than that of the person for whom the services are intended.
} 
manner as domestic service providers (market equality)." [Terra, Wattel 2011: 65]. DSTs may interfere with market equality and thus breach Art. 56 of TFES. Under Art. 56 we can also distinguished two different concepts: "discrimination" and "restriction." In contrast to the non-discrimination component, the fundamental freedoms' nonrestriction component must be understood as a "Right to freedom" (Freiheitsrecht): It is an absolute concept that operates autonomously, which means that it is independent from the treatment of other situations." [Cordewener 2004: 26]. Therefore, EU law confers upon providers of digital services (and their subsidiaries) greater legal protection than international tax treaties.

Specifically, we could mention two cases heard before Court of Justice of European Union (hereafter "CJEU") ${ }^{4}$. First case is Case C-294/97 Eurowings Luftverkehr [ECLI:EU:C:1999:524] (hereinafter referred to as "Eurowings"). The case deals with a preliminary question, whether Eurowings was obliged to add various amounts back to the taxable amount for trade tax under the Gewerbesteuergesetz (Trade Tax Law). This trade tax was calculated in two stages: first of all, it was applied to capital and earnings at a basic rate fixed uniformly for the whole of Germany at $0.2 \%$ for capital and $5 \%$ for earnings of capital companies; a rate determined separately by each municipality was then applied to the amount thus obtained. In 1993, the latter rate varied from 0\% to 515\%. [Eurowings: para 12]. CJEU observes that "any legislation of a Member State which, like that at issue in the main action, reserves a fiscal advantage to the majority of undertakings which lease goods from lessors established in that State whilst depriving those leasing from lessors established in another Member State of such an advantage gives rise to a difference of treatment based on the place of establishment of the provider of services, which is prohibited by Article 59 of the Treaty" [Eurowings: para 40].

Second important case is a Case C-385/12 Hervis Sport- és Divatkereskedelmi [ECLI:EU:C:2014:47] (hereinafter referred to as "Hervis Sport"). Company Hervis operates sports shops in Hungary under the name 'Hervis Sport'. Its direct competitors are the retail store chains 'Décathlon', 'Intersport' and 'SPG Sporcikk. The main proceedings concern the allegedly discriminatory rate of tax imposed on company Hervis, by virtue of the special tax on 'taxable persons classified as linked undertakings' This tax employed a steeply progressive tax rate to the overall turnover of that group. Therefore, Hervis was subject to an average rate of tax considerably higher than that corresponding to the taxable amount consisting solely of the turnover of its own stores. The tax payable by the Hungarian retail store chains, which are in competition with Hervis, was calculated on the basis of that

\footnotetext{
${ }^{4}$ Cases selected according to Shiers, Stoels [Shiers, Stoels 2019].
} 
taxable amount, since they are for the most part organised as sales outlets on the franchise model, have legal personality, and do not belong to a group. [Hervis Sport: para 14]. CJEU observed that this tax was disadvantageous for members of the group situated in the other EU member states. This conclusion was based on two features of the tax: the rate of that tax was steeply progressive in accordance with turnover, in particular in its upper band and that scale applied to a tax base which covers, for taxable persons belonging to a group of companies, the consolidated turnover of all the 'linked' taxable and it, at the same time, is limited to the turnover of the taxable person on an individual basis in the case of legal persons such as independent franchisees [Hervis Sport: para 34-36]. Therefore, CJEU decided that Hungarian turnover tax is incompatible with Articles 49 and 54 of TFEU.

We could observe that CJEU strictly assesses cases of discriminatory measures that could affect the position of competitors from other member states in favour of domestic companies. Our analyses strongly suggest that this is also the case with the majority of selected DSTs. Therefore, considering these decisions of CJEU, we conclude that DST in France, Italy, and Austria conflict with Art 56 of TFEU.

The other potential risk that DSTs face is their potential incompatibility with EU state aid rules. In that respect Case T-20/17 Hungary vs European Commision [ECLI: ECLI:EU:T:2019:448] was heralded as an important win for digital taxations. In our opinion, this case would have minimal impact on DSTs from the perspective of EU law. CJEU observed that reason for EJC's annulment of Commission Decision (EU) 2017/329 of 4 November 2016 on the measure SA.39235(2015/C) (ex 2015/NN) was Commission's incorrect claim that "the measure introduces in the present case an arbitrary differentiation between different groups of undertakings in a comparable legal and factual situation." (para. 121). This decision was specific for the factual circumstances of this case. Therefore, EU member states do not have carte blanche for the imposition of DSTs.

\section{OECD Model Tax Convention}

Important question in relation to DSTs is whether it falls within the scope of international tax treaties based on OECD Model Tax Convention. Concerning this matter, two distinct opinions were expressed. First opinion asserts that DSTs do not fall into the scope of OECD Model Tax Convention because they cover gross revenues instead of income. "It is most likely that the DST is not identical or substantially similar to the enumerated taxes (Author's note: within the scope of French/US taxation treaty) because-although the tax is 
borne by companies-it is imposed on the supply of digital services without regard to the economic situation of the supplier" [Forsgren, Song, Horváth 2020]. Second opinion states that gross revenue should be considered as an income and/or an element of the income, therefore it falls within the scope of OECD Model Tax Convention. "It is at least arguable that the UK DST is a tax on income or elements of income. The UK/US Treaty would therefore apply to the UK DST if it is such a tax even" [Shiers, Stoels 2019].

We could point out that OECD Model Tax Convention shall apply to taxes on income and capital imposed on behalf of a Contracting State [OECD Model Tax Convention: Art. 2(1)]. OECD Model Tax Convention offers a definition of taxes that fall within its scope as: "there shall be regarded as taxes on income and on capital all taxes imposed on total income, on total capital, or on elements of income or of capital, including taxes on gains from the alienation of movable or immovable property, taxes on the total amounts of wages or salaries paid by enterprises, as well as taxes on capital appreciation" [OECD Model Tax Convention: Art. 2(2)]. According to Commentary on Art. 2(2) of OECD Model Tax Convention "the term "direct taxes" which is far too imprecise, has therefore been avoided. It is immaterial on behalf of which authorities such taxes are imposed. The method of levying the taxes is equally immaterial: by direct assessment or by deduction at the source, in the form of surtaxes or surcharges, or as additional taxes (centimes additionnels)" [OECD 2019a: p. 225]. In our opinion, turnover taxes charged on gross revenues (generated from digital services) could be viewed as a method of levying tax on income/elements of income. Therefore, three out of four analysed GTSs (United Kingdom, France, and Italy) fall within the scope of OECD Model Tax Convention. It is not the case with AU:GTS because it is an indirect tax levied only on the prizes of digital advertisement. We believe that states whose DSTs fall within the scope of OECD Model Tax Convention should refrain from imposition of DSTs in the future because they are incompatible with the international tax regime.

At the same time, the risk of extraterritorial taxation by DST also exists. We show three ways for the calculation of tax base of DST is possible: a) DST is calculated on the amount of the fee for advertisement services, b) DST is calculated on the domestic gross revenue from supplied digital services or c) DST is calculated on the proportion of worldwide revenue according to the amount of services performed in the tax jurisdiction. Third method for the calculation of tax base (which was adopted by France and Italy) could give rise to extraterritorial taxation in case of nonresidents. This situation could occur if the commission for digital advertising is prized as a percentage of the transaction price. If, for example, French Amazon users tend to place low-value transactions, while non-French Amazon 
users tended to place higher-value transactions, the formula would overestimate the amount of revenue generated from sales to French users. (USA: 21). In that situation, a tax would be levied on the portion of the gross revenue that is in no connection to digital services performed in the state territory. That case would represent a great overextension of taxation jurisdiction on the part of the state, where the source of revenue is located. At the same time, it would constitute a violation of the tax jurisdiction of the state of taxpayer residency. Potentially, this method for the calculation of DST could lead to double taxation of a certain portion of digital services revenues.

\section{Conclusion}

After our analysis, we believe, that multilateral agreement seems like a better solution for the taxation of digital services than DSTs. First and foremost, OECD Unified approach would be consistent with the current international tax regimes. We are at worry that DSTs symbolize a dramatical shift of balance between tax jurisdictions which have been steadily and continuously built upon the net of international tax treaties during the past one hundred years. We identified significant problems concerning DSTs with respect to their selective nature and potentially discriminatory effects. Therefore, their adoption could have dramatic ramifications across international business relationships. For these reasons, we prefer OECD solutions before the wide adoption of DST.

We hope for a multilateral agreement to be reached by OECD member states. On the other hand, an old proverb states that you should "expect the best but be prepared for the worst". In case this agreement will not come to fruition, then the Slovak republic, and all other EU countries, which have not until yet adopted DST, should be prepared for the introduction of DSTs into their national legislation. We strongly suggest that, if it is the case, they should model their new DSTs in accordance with the obligations set by international (tax) law.

First and foremost, significant changes must be made in the design of threshold conditions. We recommend abolishing the two-tier mechanism of threshold conditions in favour of one national gross revenue threshold that would be determined strictly on the base of national digital services' revenues. Secondly, we recommend that this national threshold condition is not to be set too high. Otherwise, it is not possible to prevent the selective and discriminatory nature of new DSTs. Therefore, we suggest that each jurisdiction performs a statistical evaluation of its national digital service market, so the national 
threshold would reflect equal and fair taxation of domestic taxpayers as well as foreign taxpayers.

Thirdly, we recommend that more comprehensive nexus rules for DST be adopted. They should be based not only on users' IP addresses but they should reflect several other criteria. A good example is how criteria for significant economic presence were proposed by OECD. In that manner, the extraterritoriality taxation by DST could be prevented.

Extraterritoriality is an issue in the case of assessment of tax base. We highly prefer tax base to be determined by the actual prizes of the digital services (e.g., of digital advertisement) over the estimation of the tax base upon percentage of a total amount of digital services provided worldwide (FR:DST and IT:DST). The reason is simple and was mentioned earlier. If the prize of digital advertisement and other digital services is not determined as a lump sum but as a share of the profit, then taxation would cover also part of the gross revenue which would not be generated in the tax jurisdiction in question. This could result in double taxation of a certain amount of revenue from digital services.

We believe that proposed changes could help to resolve not only international tax treaty issues but also some of the EU law issues. If, for example, threshold conditions do not distinguish between worldwide and national gross revenues, then the discriminatory/restriction effect of DSTs on subsidiaries of MNE located in other EU member states would be minimized. We believe that only DST that proportionally covers domestic taxpayers as well as foreign taxpayers could pass the test under Art. 56 of TFEU and EU state's aid rules.

We are aware that proposed improvements of DSTs do not address all problematic issues concerning adoption of DSTs. If, for example, gross revenue should be covered under the definition of income in OECD Model Treaty (which is open for further discussion) - then a potential conflict with treaties based on OECD Model Treaty may happen.

From these observations, we could conclude that the AU:DST adopted in Austria has the closest features to envisioned changes of DSTs and therefore could serve as a model of DSTs in other countries (for example in Slovakia). We should also mention that besides international tax treaties, DSTs could also, in a similar respect, violate business investment treaties (hereinafter referred to as „BIS"). Therefore, it is important that, before DSTs is introduced into national legislation, detailed analysis of state's BIS should be conducted. 


\section{References}

Avi-Yonah, R. S.: INTERNATIONAL TAX AS INTERNATIONAL LAW An Analysis of the International Tax Regime, Campbridge: Cambridge University Press, 2003.

Babčák, V.: Daňové parvo na Slovensku a v EU [Tax law in Slovakia and EU], Bratislava: EPOS, 2020.

Cockfield, A. J.: Designing Tax Policy for the Digital Biosphere: How the Internet is Changing Tax Laws, Connecticut Law Review, 34, 2020.

Cordewener, A.: The prohibition of discrimination and restriction within the framework of the fully integrated internal market (in:) Vanistendael, F. (eds.): EU Freedoms and Taxation, Amsterdam: IBDF, 2004.

Lemonnier, M.: Interpretation of the tax law in France. Selected problems, Financial Law Review, nr. 5 [2], 2020.

Hrabčák, L - Popovič, A.: On certain issues of digital service taxes, Financial Law Review, nr.17 [1], 2020.

Forsgren, Ch. - Song, S. - Horváth,D.: Digital Services Taxes: Do They Comply with International Tax, Trade, and EU Law?, Tax Foundation: 2020. Available at: https://taxfoundation.org/france-digital-tax-international-tax-law-trade-law-eu-law/\# f tn11, accessed: $10^{\text {th }}$ September 2020.

Olbert, M. - Spengel, C.: International Taxation in the Digital Economy: Challenge Accepted?, World Tax Journal 9 [1], 2020.

Shiers, R - Stoel, J. T.: Is the DST compatible with the UK's international obligations?, Hogan Lovells, 2020

Available at: https://www.hoganlovells.com/en/publications/is-the-dst-compatible-with-theuks-international obligations, accessed: 10th September 2020.

Terra, B. J. M. - Wattel, P. J.: European Tax Law - 6th eds. Alphen aan den Rijn: Kluwer Law International, 2012.

\section{Legal Acts}

Digital Tax Act 2020.

French digital services tax Law.

Italian Budget Law 2020.

United Kingdom Finance Bill 2020.

\section{Court rulings}

Court of Justice of European Union's ruling in Case C-294/97 Eurowings Luftverkehr [ECLI:EU:C:1999:524].

Court of Justice of European Union's ruling in Case C-385/12 Hervis Sport- és Divatkereskedelmi [ECLI:EU:C:2014:47].

Court of Justice of European Union's ruling in Case T-20/17 Hungary vs European Commision [ECLI: ECLI:EU:T:2019:448].

\section{Other official documents}

OECD (2015), Addressing the Tax Challenges of the Digital Economy, Action 1 - 2015 Final Report, OECD/G20 Base Erosion and Profit Shifting Project, OECD Publishing, Paris.

Available at: https://doi.org/10.1787/9789264241046-en, accessed: $10^{\text {th }}$ September 2020.

OECD (2019a), Model Tax Convention on Income and Capital 2017 (Full Version), OECD Publishing, Paris.

Available at: https://doi.org/10.1787/g2g972ee-en, accessed: 10

OECD (2019b): OECD/G20 Base Erosion and Profit Shifting Project Addressing the Tax Challenges of the Digitalisation of the Economy Public Consultation Document.

Available at: https://www.oecd.org/tax/beps/public-consultation-document-addressing-thetax-challe nges-of-the-digitalisation-of-the-economy .pdf, accessed: $10^{\text {th }}$ September 2020.

OECD (2019c): Programme of Work to Develop a Consensus Solution to the Tax Challenges Arising from the Digitalisation of the Economy, OECD/G20 Inclusive Framework on BEPS, OECD, Paris. 
Available at: www.oecd.org/tax/beps/programme-of-work-to-develop-aconsensus-solutionto-the-tax-challenges-arising-from-the-digitalisation-of-the-economy.htm, accessed: $10^{\text {th }}$ September 2020.

OECD 2020a: Statement by the OECD/G20 Inclusive Framework on BEPS on the Two-Pillar Approach to Address the Tax Challenges Arising from the Digitalisation of the Economy in January 2020, OECD/G20 Inclusive Framework on BEPS, OECD, Paris.

Available at: www.oecd.org/tax/beps/statement-by-the-oecd-g20-inclusive-framework-onbeps-january-2020.pdf, accessed: 10th September 2020.

OECD 2020c: OECD/G20 Inclusive Framework on BEPS Progress report July 2019 to - July 2020 Available at: http://www.oecd.org/tax/beps/oecd-g20-inclusive-framework-on-bepsprogress-report-july-2019-july-2020.pdf, accessed: 10 ${ }^{\text {th }}$ September 2020.

US 2019: Report on France's Digital Services Tax Prepared in the Investigation under Section 301 of the Trade Act of 1974 Office of the United States Trade Representative Ambassador Robert E. Lighthizer on December 2, 2019

Available at:

https://ustr.gov/sites/default/files/Report_On_France\%27s_Digital_Services_Tax.pdf, accessed: $10^{\text {th }}$ September 2020.

\section{Internet Resources}

La web tax italiana: prospettive e problemi [Web tax in Italy: perspectives and problems], Available at: https://osservatoriocpi.unicatt.it/cpi-archivio-studi-e-analisi-la-web-tax-italianaprospettive-e-problemi, accessed: $10^{\text {th }}$ September 2020.

France agrees to delay new tax on tech giants Available at: https://www.bbc.com/news/business-51192369, accessed: $10^{\text {th }}$ September 2020. 